I wish to thank Dr K. A. Lord for the loan of and instruction in the use of his.electrophoresis apparatus; and Dr R. Markham for his hospitality and advice during the experiment on the detection of nucleotides.

\section{REFERENCES}

Axelrod, B. (1947). J. biol. Chem. 167, 57.

Bell, R. N. (1947). Industr. Engng Chem. 39, 136.

Boman, H. G. \& Kaletta, U. (1956). Nature, Lond., 178, 1394.

Boman, H. G. \& Westlund, L. E. (1956). Arch. Biochem. Biophys. 64, 217.

Holden, M. \& Pirie, N. W. (1955a). Biochem. J. 60, 39.

Holden, M. \& Pirie, N. W. (1955b). Biochem. J. 60, 46.

Holden, M. \& Pirie, N. W. (1955c). Biochem. J. 60, 53.

Ito, E., Kondo, S. \& Watanabe, S. (1955). J. Biochem., Tokyo, 42, 6.

Kornberg, S. R. (1956). J. biol. Chem. 218, 23.

McCullough, J. F., Van Wazer, J. R. \& Griffith, E. J. (1956). $J$. Amer. chem. Soc. 78, 4528.

Markham, R. \& Smith, J. D. (1949). Biochem. J. 45, 294.

Markham, R. \& Smith, J. D. (1951). Biochem. J. 49, 401.

Markham, R. \& Smith, J. D. (1952a). Biochem. J. 52, 552.
Markham, R. \& Smith, J. D. (1952b). Biochem. J. 52, 565.

Markham, R. \& Smith, J. D. (1954). In The Proteins, vol. 2A, p. 1. Ed. by Neurath, H. \& Bailey, K. New York: Academic Press.

Martin, A. J. P. \& Porter, R. R. (1951). Biochem. J. 49, 215.

Mattenheimer, H. (1956). Hoppe-Seyl. Z. 303, 125.

Mokrasch, L. C. \& McGilvery, R. W. (1956). J. biol. Chem. 221, 909.

Neuberg, C., Grauer, A. \& Mandl, I. (1950). Enzymologia, 14, 157.

Peters, T. V. \& Rieman, W. (1956). Analyt. chim. acta, 14, 131.

Pierpoint, W. S. (1956). Biochim. biophys. Acta, 21, 136.

Pierpoint, W. S. (1957). Biochem. J. 65, 67.

Roberts, D. W. A. (1956). J. biol. Chem. 219, 711.

Roche, J. (1950). In The Enzymes, vol. 1, part 1, p. 473. Ed. by Sumner, J. B. \& Myrbäck, K. New York: Academic Press.

Singer, T. P. \& Kearney, E. B. (1950). Arch. Biochem. 29, 190.

Tsuboi, K. K., Wiener, G. \& Hudson, P. B. (1957). J. biol. Chem. 224, 621.

Woods, E. F. \& Gillespie, J. M. (1952). Aust. J. biol. Sci. 6, 130.

\title{
Calcium and Magnesium Metabolism in Calves
}

\section{PLASMA LEVELS AND RETENTION IN MILK-FED CALVES}

\author{
BY R. H. SMITH \\ National Institute for Research in Dairying, University of Reading
}

(Received 14 November 1956)

Sheep and cattle are the only animals known to be subject to a clinical disorder apparently due to magnesium deficiency, when receiving diets not themselves grossly deficient in magnesium. The disorder is characterized by hypomagnesaemia and culminates in extreme cases in convulsions which are often fatal. It occurs in adult sheep and cattle under a variety of conditions, but most frequently shortly after they have started to graze young quickly growing herbage. The subject has been reviewed by Russell (1944) and Blaxter \& McGill (1956). Duncan, Huffman \& Robinson (1935) first showed that calves, fed basically on milk for an abnormal length of time, also develop hypomagnesaemia. This finding has frequently been confirmed (Wise, Petersen \& Gullickson, 1939; Huffman, Conley, Lightfoot \& Duncan, 1941; Blaxter \& Sharman, 1955). Occasionally hypocalcaemia has also been reported in milk-fed calves (Huffman \& Robinson, 1926; Parr, 1957). Two principal reasons have been suggested to explain the development of hypomagnesaemia under these conditions: $(a)$ that it is due to a simple dietary deficiency of magnesium (Blaxter, 1956); (b) that the properties of the milk diet are such that utilization of magnesium is impaired (Huffman et al. 1941).

The present work was undertaken in an attempt. to throw further light on this problem.

\section{EXPERIMENTAL}

\section{Animals}

Two sets of calves were used. One set was kept from 1954 to 1955 (nos. 85, 86 and 87) and the other set from 1955 to 1956 (nos. 1, 3, 4, 5, 6, 7, 8, 11). All were male shorthorns except for no. 4, which was a female shorthorn, and no. 11, which was a male Friesian. All the males except nos. 1 and 11 were castrated at 2-3 weeks of age. The calves were removed from their dams 4 days after birth and subsequently fed twice daily from a bucket. Their diets consisted almost exclusively of whole milk in the amounts shown in Table 1 with daily additions of $0.4 \mathrm{~g}$. of $\mathrm{FeCl}_{3}, 6 \mathrm{H}_{2} \mathrm{O}, 0.04 \mathrm{~g}$. of $\mathrm{MnSO}_{4}, 4 \mathrm{H}_{2} \mathrm{O}$ and $0.04 \mathrm{~g}$. of $\mathrm{CuSO}_{4}, 5 \mathrm{H}_{2} \mathrm{O}$ from 2 months and double these amounts from 6 months. The amounts of milk fed were restricted so that the calves did not generally grow at the optimum rate. This was done to avoid digestive disorders as far as possible and to obtain a uniform treatment. Many of the calves had diarrhoea for a day or two but some developed persistent digestive disturbances; the latter were usually removed from the experiment if they 
did not die. Calf 5 died in this way at 8 weeks of age and calf 8 was removed at 10 weeks of age, but the data which will be presented for these calves were obtained before they showed any signs of digestive disorders. Calf 7 was the only calf for which data were obtained during a period of persistent disorder. This calf was normal up to 16 weeks of age, but it then developed recurrent slight diarrhoea and a poor appetite and grew abnormally slowly.

The magnesium and calcium content of the milk fed during most of the experimental period is given in Fig. 1. Magnesium supplements, when used, were added to the milk either as the sulphate (calves 85,86 and 8 ) or as the chloride (calves 1, 3 and 7). Calf 6 was given the sulphate up to 27 weeks of age and the chloride subsequently. A supplement equivalent to $10 \mathrm{mg}$. of magnesium $/ 100 \mathrm{ml}$. of diet was given to calves 6 and 8 from 5 weeks of age but supplements were only given to the other calves, as a palliative measure, when severe hypomagnesaemia was present. Vitamin D supplements were added to the diet as aqueous suspensions, except that vitamin $\mathrm{D}_{3}$ was added as a solution in arachis oil when it was fed to calf 11 at a rate of 140000 i.u./day. Calves 85,86 and 87 received a supplement of 7000 i.u. of vitamin $D_{2}$ /day from 14 weeks of age and 17000 i.u. of vitamin $D_{2} /$ day from 30 weeks. Calves 1,4 and 6 received 7000 i.u. of vitamin $D_{2}$ /day from 9 weeks of age.
The supplement was increased to 70000 i.u./day for calves 1 and 6 when they were showing signs of faulty calcium metabolism and for calf 4 at 34 weeks. Calves, 3, 7 and 11 were not given vitamin $D$ until they were suffering from advanced hypocalcaemia (except that calf 3 inadvertently received 7000 i.u. of vitamin $\mathrm{D}_{2}$ /day from 9 to 11 weeks). Calves 3 and 7 were then given 70000 i.u. of vitamin $D_{2} /$ day and calf 11 was given 140000 i.u. of vitamin $D_{3} /$ day. Calf 5 died and calf 8 was removed from the experiment without receiving vitamin $\mathrm{D}$ supplements.

The animals were kept in stalls away from direct sunlight and muzzled. Wood shavings were used as bedding. Some of the male calves were used for balance experiments and for this purpose they were transferred to metal metabolism cages. These cages were constructed so that urine passed through a mesh floor into a stainless-steel tray. It was collected in a bottle containing acetic acid (about $1 \%$ of the final urine volume) and toluene. The urine was filtered and kept under toluene in a refrigerator before analysis. Faeces were collected in a rubber bag fastened to a harness worn by the animal. A sample, comprising about $90 \%$ of the faeces collected, was dried at $100^{\circ}$, milled and well mixed before analysis. Collections were usually made for 8 consecutive days, the samples for the first and last 4 days being analysed separately. Blood samples were taken at approximately

\section{Table 1. Milk intake of the calves at different ages}

Values are expressed as 1./day. The intake shown by the right-hand figure for each calf, or group of calves, was continued to the end of the experiment.

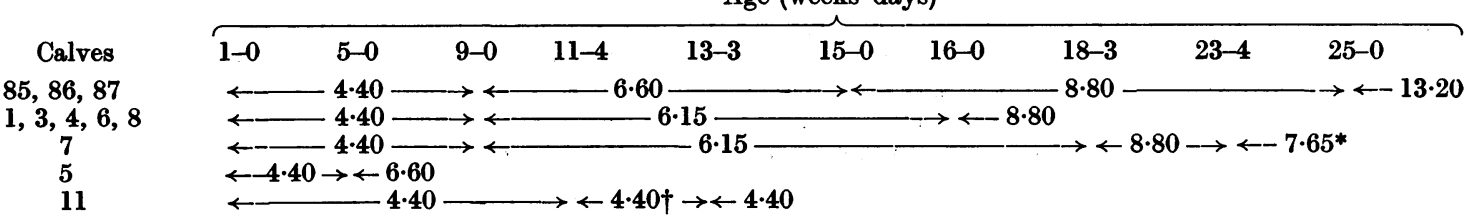

* Calf 7 sometimes refused part of its milk during this period. The figure given is an average.

$\dagger$ Calf 11 received $0 \cdot 88$. of colostrum (159 mg. of calcium/100 ml.; $29 \cdot 2 \mathrm{mg}$. of magnesium/100 ml.) and 3.52 1 . of milk during this period.

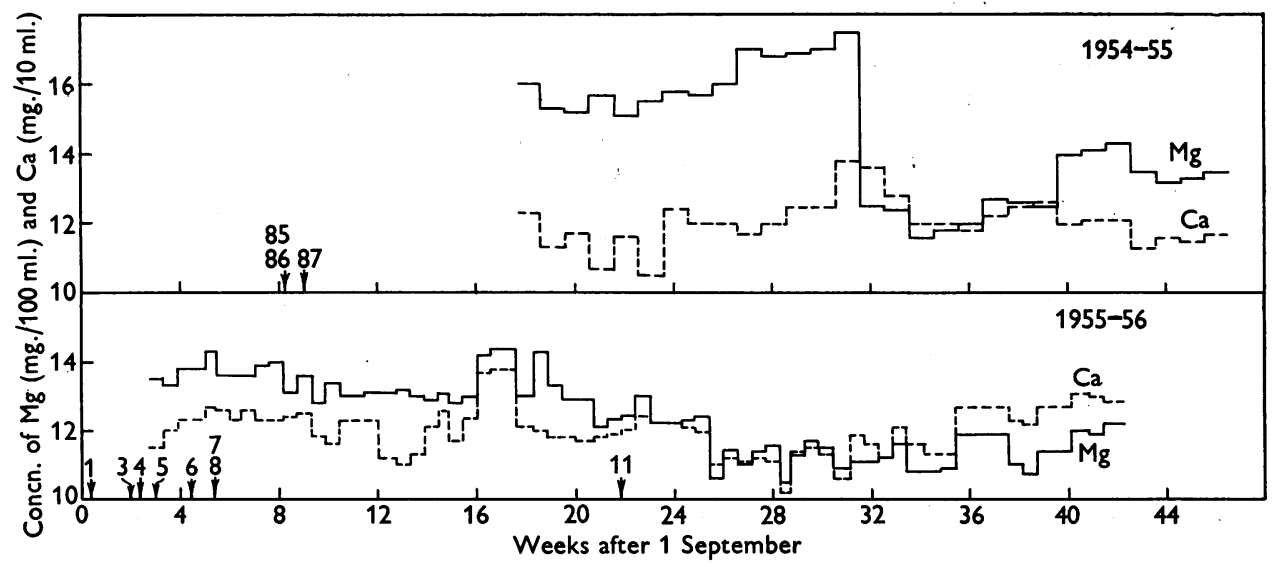

Fig. 1. Calcium and magnesium content (excluding supplementary magnesium) of the milk fed to the calves. Arrows indicate the dates of birth of the various calves. Milk analyses were not carried out during about the first 9 weeks of the 1954-55 experiments and the first 2 weeks of the 1955-56 experiments. 
weekly intervals from the jugular vein, just before or just after the morning feed, into centrifuge tubes containing heparin. The blood was centrifuged within $15 \mathrm{~min}$. and the plasma siphoned off. The calves were usually weighed at weekly intervals.

\section{Analysis}

Plasma. Inorganic phosphorus was determined by the method of Fiske \& Subbarow (1925). Calcium and magnesium were determined by the method of Green \& Allcroft as described by Godden (1937). Ultrafilterable calcium and magnesium were determined by applying this method to plasma ultrafiltrates prepared by the method described by Gregory (1954) for the preparation of milk ultrafiltrates.

Milk. A $5 \mathrm{ml}$. sample was taken at each feed and added, with shaking, to $20 \mathrm{ml}$. of $10 \%(\mathrm{w} / \mathrm{v})$ trichloroacetic acid. The mixture was kept for 2 days at $37^{\circ}$ and filtered through Whatman no. 44 paper. Collected filtrates were bulked, usually in 4- or 7-day batches, diluted 2.5 times and $5 \mathrm{ml}$. samples added to $15 \mathrm{ml}$. conical centrifuge tubes. Methyl orange was used as indicator and saturated sodium acetate was added dropwise to give a pH of about 4-5. Calcium and magnesium were then determined as for plasma.

Urine. In general a milk-fed calf produces a larger volume of more dilute urine than an animal receiving solid food. Since, in addition, many of our determinations were made on hypomagnesaemic animals excreting little magnesium in the urine it was necessary to use a technique for very dilute solutions. A $25 \mathrm{ml}$. sample of urine was evaporated to dryness in a silica crucible on a steam bath. After cooling, about $1 \mathrm{ml}$. of $5 \mathrm{~N}$-nitric acid was added, and the mixture again evaporated to dryness first on a steam bath then in an oven at $100^{\circ}$ overnight. The crucible was transferred to a muffle furnace, heated carefully at $180-200^{\circ}$ until fuming ceased and the residue ashed at $450^{\circ}$ overnight. The white ash was digested with $2 \mathrm{ml}$. of $2 \mathrm{~N}$-hydrochloric acid on a steam bath and the solution and washings were transferred to a $15 \mathrm{ml}$. centrifuge tube (total volume 5-6 ml.). The $\mathrm{pH}$ was adjusted to 4-5 and calcium and magnesium were determined as before.

Faeces. About $1 \mathrm{~g}$. of the dried faeces was ashed at $550^{\circ}$ for $24 \mathrm{hr}$. The ash was digested on a steam bath with $5 \mathrm{ml}$. of $2 \mathrm{~N}$-hydrochloric acid and the solution and washings were made up to $250 \mathrm{ml}$. A sample of this solution (5 ml.) was pipetted into a $15 \mathrm{ml}$. centrifuge tube, the $\mathrm{pH}$ adjusted to 4-5 and calcium and magnesium were determined as before, except that the magnesium ammonium phosphate precipitate was dissolved in $0.5 \mathrm{ml}$. of $10 \mathrm{~N}$-sulphuric acid, the solution made up to a suitable volume and a sample used for colour development.

\section{RESULTS}

\section{Plasma levels}

Magnesium. Duncan, Lightfoot \& Huffman (1938) found little change in the mean plasmamagnesium level with age in a group of normally reared calves but there was considerable individual variation. They found, for example, for 163 determinations on calves up to 1 month of age a mean value of $2.39 \mathrm{mg}$. $/ 100 \mathrm{ml}$. (s.E. 0.02 , range 1.78 $3 \cdot 14$ ) and for 98 determinations on calves of between 10 and 11 months a mean value of $2.54 \mathrm{mg} . / 100 \mathrm{ml}$. (s.E. $0 \cdot 05$, range $1 \cdot 71-3 \cdot 60$ ). Our calves all main- tained normal plasma-magnesium values (between about 2.2 and $2.7 \mathrm{mg} . / 100 \mathrm{ml}$.) for a period of time after birth but the level eventually began to fall at a point and at a subsequent rate which varied considerably from animal to animal. In all the calves showing hypomagnesaemia (except calf 11 which was removed from the experiment at 17 weeks of age) the plasma magnesium eventually fell to between about 0.4 and $0.8 \mathrm{mg} . / 100 \mathrm{ml}$, where it remained, unless a magnesium supplement was given, for 8-15 weeks until the animals were slaughtered or died. Detailed results for two of the calves are shown in Fig. 2.

Although a high level of magnesium in the diet can influence the plasma magnesium in milk-fed calves (see below and Huffman \& Duncan, 1936), there was in our experiments no consistent relationship from animal to animal between the rate of onset of hypomagnesaemia and the variations in the amounts of magnesium in the diets. For example, calves 85 and 4 showed, respectively, the most rapid and the slowest development of hypomagnesaemia of the calves which we examined. In calf 85 the plasma magnesium had fallen below $1.62 \mathrm{mg}$./ $100 \mathrm{ml}$., which was the lowest value observed by Duncan et al. (1938) in normal calves, by 9 weeks of age and below $1.0 \mathrm{mg} . / 100 \mathrm{ml}$. by 11.5 weeks. In calf 4 the corresponding ages were 26 and 36 weeks. This was in spite of the fact that calf 85 received milk containing $15-16 \mathrm{mg}$. of magnesium $/ 100 \mathrm{ml}$. during the onset of hypomagnesaemia, whereas calf 4 received milk containing only about $11-14 \mathrm{mg}$. of magnesium/100 ml. (see Fig. 1). Calf 6, which received supplemented milk containing about $21-$ $24 \mathrm{mg}$. of magnesium/100 ml. from 5 weeks of age, developed hypomagnesaemia more rapidly than calf 4 , the plasma magnesium falling below 1.62 and $1.0 \mathrm{mg} . / 100 \mathrm{ml}$. by 23 and 27.5 weeks respectively.

When daily additions of 7000 i.u. of vitamin D were made to the diet before the onset of hypomagnesaemia, the subsequent appearance of this condition was not prevented (calves $1,3,4$ and 6). Later increases in the intake of vitamin $D$ by these calves and the addition of vitamin $D$ to the diet of calves which became hypomagnesaemic before receiving supplementary vitamin $D$ (calves 85,86 , 87,7 and 11) did not alleviate the condition to any appreciable extent. In three of the calves $(86,87$ and 11) there was a small rise in the plasma mag. nesium of about $0.4 \mathrm{mg} . / 100 \mathrm{ml}$. shortly after the first administration of vitamin $D$, but the effect was only temporary and of doubtful significance.

When calves 1,3 and 7 were suffering from wellestablished hypomagnesaemia (plasma magnesium below $0.8 \mathrm{mg} . / 100 \mathrm{ml}$. for about 4 weeks) the addition to their diet of supplementary inorganic magnesium equivalent to $10 \mathrm{mg} . / 100 \mathrm{ml}$. of diet had little or no effect on the plasma magnesium 
(see, for example, Fig. 2). Calves 85 and 86 in a similar condition showed a marked improvement in plasma magnesium, however (this level increasing progressively from 0.7 to $1.8 \mathrm{mg} . / 100 \mathrm{ml}$. in about 7 weeks and from 0.6 to $1.3 \mathrm{mg} . / 100 \mathrm{ml}$. in about 2 weeks respectively), when their diet was supplemented with inorganic magnesium equivalent to $20 \mathrm{mg} . / 100 \mathrm{ml}$.

Calcium. With normal feeding McSherry \& Grinyer (1954) found no significant difference between the serum-calcium levels of calves up to 10 weeks of age on the one hand and calves aged 4-10 months on the other. Over the whole range, in determinations on 40 calves, they found a mean value of $10.7 \mathrm{mg} . / 100 \mathrm{ml}$. (s.E. 0.4 ). For the first few weeks after birth the plasma-calcium levels of all our calves remained reasonably constant (maximum. variation $\pm 10 \%$, with mean values ranging from 11 to $15 \mathrm{mg} . / 100 \mathrm{ml}$. for different animals) but some subsequently developed hypocalcaemia. It was found that in calves which developed hypomagnesaemia before their diet was supplemented with vitamin $\mathrm{D}$ (calves $85,86,87,7$ and 11) there was also a fall in plasma calcium. The falls in plasma magnesium and calcium respectively began at about the same time and subsequently developed at about the same rate for any one calf. Thus calf 85, which showed the most rapid fall in plasma magnesium, also showed the most rapid fall in plasma calcium (to about $50 \%$ of normal by 12 weeks of age). In all the calves this relationship was destroyed when supplementary vitamin $D$ was added to the diet. Complete restoration of normal plasma calcium, from levels about $50-80 \%$ of normal, occurred in about 4 weeks for calves 85, 86 and 87, which received 7000 i.u. of vitamin $D_{2} /$ day, and in about 1 week for calves 7 and 11, which received 70000 i.u. of vitamin $D_{2} /$ day and 140000 i.u. of vitamin $\mathrm{D}_{3}$ /day respectively. Detailed results for calf 7 are given in Fig. 2. When the diet was supplemented with 7000 i.u. of vitamin $\mathrm{D}_{2}$ /day before the plasma magnesium began to fall (calves 1, 3,4 and 6) the subsequent appearance of hypomagnesaemia was not accompanied by hypocalcaemia. This is illustrated for calf 1 in Fig. 2. Calf 3 received 7000 i.u. of vitamin $\mathrm{D}_{2}$ /day only from 9 to 11 weeks of age. Hypocalcaemia appeared 6 weeks after it was stopped and the plasma calcium had fallen to about $65 \%$ of normal before a daily supplement of 70000 i.u. of vitamin $D_{2}$ restored normal levels within 1 week. Calf 6 began to show hypocalcaemia at 27 weeks of age in spite of receiving a daily supplement of 7000 i.u. of vitamin $D_{2}$ and the plasma calcium had fallen to about $55 \%$ of normal by 31 weeks. An increase in the supplement to $70000 \mathrm{i} . u$./day restored normal levels within 1 week.

Other constituents. Inorganic phosphorus determinations were usually made on the same plasma samples as those used for the determinations of magnesium and calcium. No consistent marked changes were observed corresponding to the onset of hypomagnesaemia or hypocalcaemia or to the addition of vitamin $\mathrm{D}$ to the diet. Thus during the onset of hypocalcaemia in calf 7 , in a period of 3 weeks in which the plasma calcium dropped from

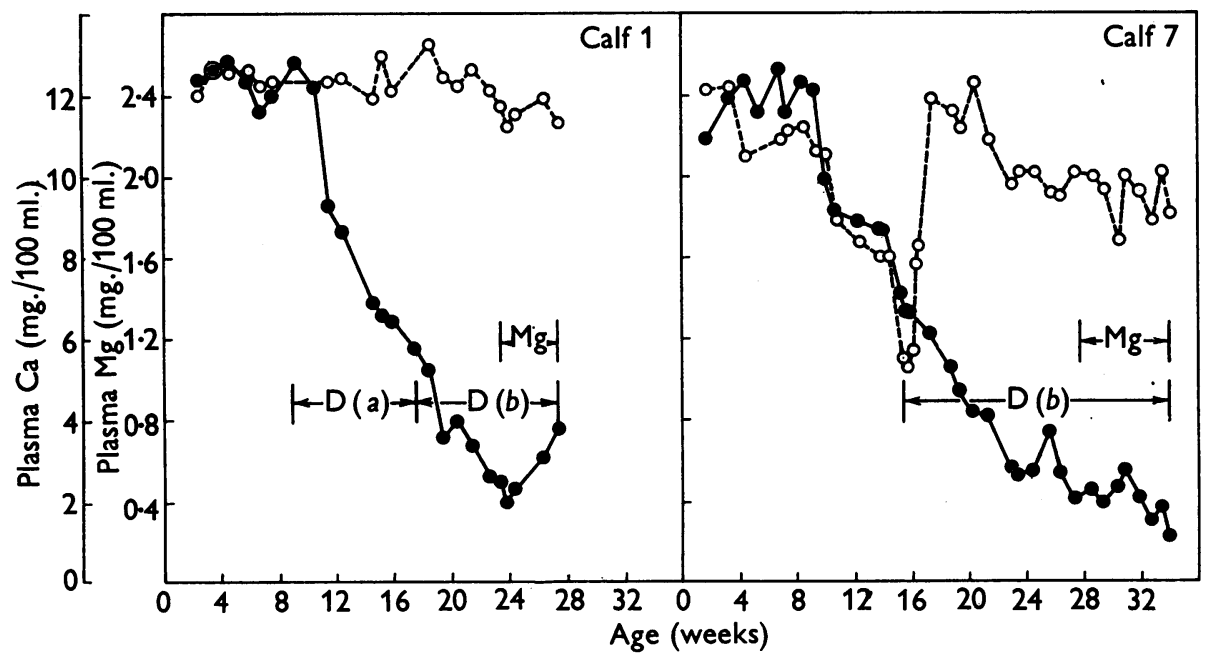

Fig. 2. Changes in plasma magnesium (-) and calcium (O- O) levels of calves 1 and 7. Periods during which supplements were added to the diet are indicated $\left[\mathrm{D}(a): 7000\right.$ i.u. of vitamin $\mathrm{D}_{2} /$ day; $\mathrm{D}(b): 70000$ i.u. of vitamin $\mathrm{D}_{2} /$ day; $\mathrm{Mg}$ : magnesium (as the chloride) equivalent to $10 \mathrm{mg} . / 100 \mathrm{ml}$. of diet]. The magnesium content of the unsupplemented milk is given in Fig. 1 and the amounts of milk fed are given in Table 1. 
8.4 to $5.7 \mathrm{mg} . / 100 \mathrm{ml}$., the plasma inorganic phosphorus level (mean of four samples) was $7.3 \mathrm{mg}$./ $100 \mathrm{ml}$. Mean values on four samples taken over a period of 4 weeks immediately after recovery from this condition after the addition of vitamin $D$ to the diet were $11.1 \mathrm{mg} . / 100 \mathrm{ml}$. for plasma calcium and $7 \cdot 4 \mathrm{mg} . / 100 \mathrm{ml}$. for plasma inorganic phosphorus. The average inorganic phosphorus value for 15 plasma samples taken from calves $1,3,4,6,7$ and 87, between 6 and 10 weeks of age before they were suffering from appreciable hypomagnesaemia, was $7.8 \mathrm{mg} . / 100 \mathrm{ml}$. The corresponding figure for twenty-four plasma samples taken from these calves when they were in a condition of advanced hypomagnesaemia, with plasma-magnesium values less than $0.6 \mathrm{mg} . / 100 \mathrm{ml}$., was $7.6 \mathrm{mg} . / 100 \mathrm{ml}$. With normally fed calves McSherry \& Grinyer (1954) found no significant difference between the serum inorganic phosphorus levels of calves up to 10 weeks of age on the one hand and calves aged 4-10 months on the other. Over the whole range, in determinations on forty calves, they found a mean value of $7 \cdot 7 \mathrm{mg} . / 100 \mathrm{ml}$. (s.E. $0 \cdot 8$ ).

Many of the plasma samples from calves 85, 86 and 87 were also used for the determination of ultrafilterable magnesium and calcium. The proportions of plasma magnesium and calcium which were ultrafilterable (mean values 79 and $42 \%$ respectively for calves between 2 and 9 months of age) were found to be independent of the total levels of these constituents.

\section{Balance experiments}

These were carried out with calves $1,3,6$ and 7 at approximately monthly intervals from a few weeks after birth until after they had become grossly hypomagnesaemic. Calf 11 was examined at about 11 and 16 weeks of age. Calves 5 and 8 were used only for experiments at an early age. The balance experiments recorded here were never carried out when diarrhoea was present.

Magnesium. Results on some of the calves up to
9 weeks of age are given in Table 2. These calves and calves 7 (see Fig. 3) and 5 (39\% retention, $33 \%$ urine excretion) showed values for the sum of retention and urinary excretion of between 64 and $81 \%$ of the dietary magnesium at ages less than 5 weeks. These values represent the percentage of dietary magnesium absorbed without taking into account the amount of endogenous faecal excretion. The results of Blaxter \& Rook (1954) for the faecal excretion of young calves on a magnesium-free diet suggest that this might have been equivalent to about 10-15\% of the intake for the above-mentioned calves. It seems therefore, as a conservative estimate, that for the first few weeks after birth the calves were able to absorb about 75-90\% of their dietary magnesium. By 7-9 weeks of age, however, the ability to utilize dietary magnesium had dropped markedly in calves 1,3 and 8. Calf 7 was not examined between 7 and 9 weeks of age, but it showed a similar change in magnesium utilization by about 6 weeks of age (Fig. 3). This fall in magnesium utilization continued with increasing age in calves 1,3 and 7 (calf 8 was not examined further) until little or no magnesium was retained. These changes are illustrated for calves 1 and 7 in Fig. 3. Calf 3 showed a somewhat slower fall, retaining 19 , $11,9,0$ and $9 \%$ of the dietary magnesium at 13,18 , 22, 27 and 30 weeks respectively. Calf 11 showed a poor ability to retain dietary magnesium when it was examined at 11 and 16 weeks (17 and $5 \%$ respectively). Calf 6 was exceptional in that its magnesium retention had not changed appreciably by 7-9 weeks and, although the retention subsequently fell, the fall was slower than for the other calves $(20,28,0$ and $11 \%$ of the dietary magnesium was retained at 14, 21, 29 and 35 weeks respectively). During the time before the commencement of hypomagnesaemia the urine excretion of magnesium of all the calves fell as they got older. This presumably reflected the decreasing ability of the calves to utilize dietary magnesium. When examinations were made after the plasma magnesium had

\section{Table 2. Calcium-and magnesium-balance results from calves at different ages}

All the figures refer to 8-day periods within the stated age ranges. The calves received 4.40 l. of milk/day. Calves 6 and 8 received a $\mathrm{MgSO}_{4}$ supplement from 5 weeks. Excretion of calcium in the urine was at all times negligible (less than $1 \%$ of the intake).

\begin{tabular}{|c|c|c|c|c|c|c|}
\hline Calf & $\begin{array}{l}\text { Age range } \\
\text { (weeks) }\end{array}$ & $\underset{\text { (g.) }}{\mathrm{Ca} \text { intake }}$ & $\underset{\text { (g.) }}{\text { Mg intake }}$ & $\begin{array}{l}\text { Ca retention } \\
\text { (\% of intake) }\end{array}$ & $\begin{array}{l}\mathrm{Mg} \text { retention } \\
\text { (\% of intake) }\end{array}$ & $\begin{array}{l}\mathrm{Mg} \text { excretion } \\
\text { in urine } \\
(\% \text { of intake) }\end{array}$ \\
\hline 1 & $\begin{array}{l}2-5 \\
7-9\end{array}$ & $\begin{array}{l}41 \cdot 5 \\
43 \cdot 9\end{array}$ & $\begin{array}{l}4 \cdot 72 \\
4 \cdot 71\end{array}$ & $\begin{array}{l}97 \\
79\end{array}$ & $\begin{array}{l}46 \\
25\end{array}$ & $\begin{array}{l}25 \\
12\end{array}$ \\
\hline 3 & $\begin{array}{l}2-5 \\
7-9\end{array}$ & $\begin{array}{l}43 \cdot 4 \\
40 \cdot 8\end{array}$ & $\begin{array}{l}4 \cdot 86 \\
4 \cdot 72\end{array}$ & $\begin{array}{l}97 \\
79\end{array}$ & $\begin{array}{l}45 \\
25\end{array}$ & $\begin{array}{r}34 \\
6\end{array}$ \\
\hline 6 & $\begin{array}{l}2-5 \\
7-9\end{array}$ & $\begin{array}{l}43 \cdot 9 \\
40 \cdot 1\end{array}$ & $\begin{array}{l}4 \cdot 79 \\
8 \cdot 18\end{array}$ & $\begin{array}{l}94 \\
89\end{array}$ & $\begin{array}{l}47 \\
50\end{array}$ & $\begin{array}{r}22 \\
8\end{array}$ \\
\hline 8 & $\begin{array}{l}2-5 \\
7-9\end{array}$ & $\begin{array}{l}41 \cdot 2 \\
40 \cdot 2\end{array}$ & $\begin{array}{l}4 \cdot 62 \\
8 \cdot 14\end{array}$ & $\begin{array}{l}86 \\
59\end{array}$ & $\begin{array}{l}51 \\
32\end{array}$ & $\begin{array}{r}13 \\
5\end{array}$ \\
\hline
\end{tabular}


begun to fall, it was found that the urine excretion had reached a very low residual value (4-10 mg./ day), which was not appreciably affected by further falls in the plasma-magnesium level. In no experiments did the addition of vitamin $D$ to the diet appear to affect appreciably the utilization of magnesium (see, for example, Fig. 3).

Calcium. The results given in Table 2 show that there was a marked fall in the retention of calcium by calves 1, 3 and 8 between 2-5 weeks of age on the one hand and 7-9 weeks of age on the other hand. Calf 6 showed a small fall in calcium retention during this period. Calf 7 showed a similar fall between about 2 and 6 weeks of age (Fig. 3). When vitamin D supplements were withheld from the diet this decrease in calcium retention continued with further increase in age. This effect is shown for calf 7 in Fig. 3 and was also observed for calf 3 (67 and $39 \%$ retention at 13 and 18 weeks respectively) and, assuming an initial calcium retention similar to that of the other calves, for calf $11(66 \%$ retention at 11 weeks). Calf 1 also showed a continued fall in calcium retention in spite of a daily supplement of 7000 i.u. of vitamin $D_{2}$ from 9 weeks (Fig. 3). Calf 6, which also received this supplement of vitamin $\mathrm{D}_{2}$ from 9 weeks, continued to retain calcium efficiently for a considerable time $(88 \%$ retention at both 14 and 22 weeks), but by 29 weeks it was in negative calcium balance (loss $11 \%$ of intake). In all these calves a considerable improvement in calcium retention was rapidly brought about and maintained by giving a daily supplement of 70000 i.u. of vitamin $D_{2}(140000$ i.u. of vitamin $\mathrm{D}_{3}$ for calf 11). For a period beginning 2-3 weeks after starting such a supplement, calf 3 retained $80 \%$ of the dietary calcium (at 22 weeks of age), calf 6 retained $85 \%$ (at 35 weeks) and calf 11 retained $90 \%$ (at 16 weeks). Results are given in detail for calves 1 and 7 in Fig. 3. Calf 7 showed a smaller improvement in calcium retention than the other calves, probably because of what appeared to be a general digestive impairment, which began at about 16 weeks. At no time, even with daily intakes of 70000 or $140000 \mathrm{i}$.u. of vitamin D, was the

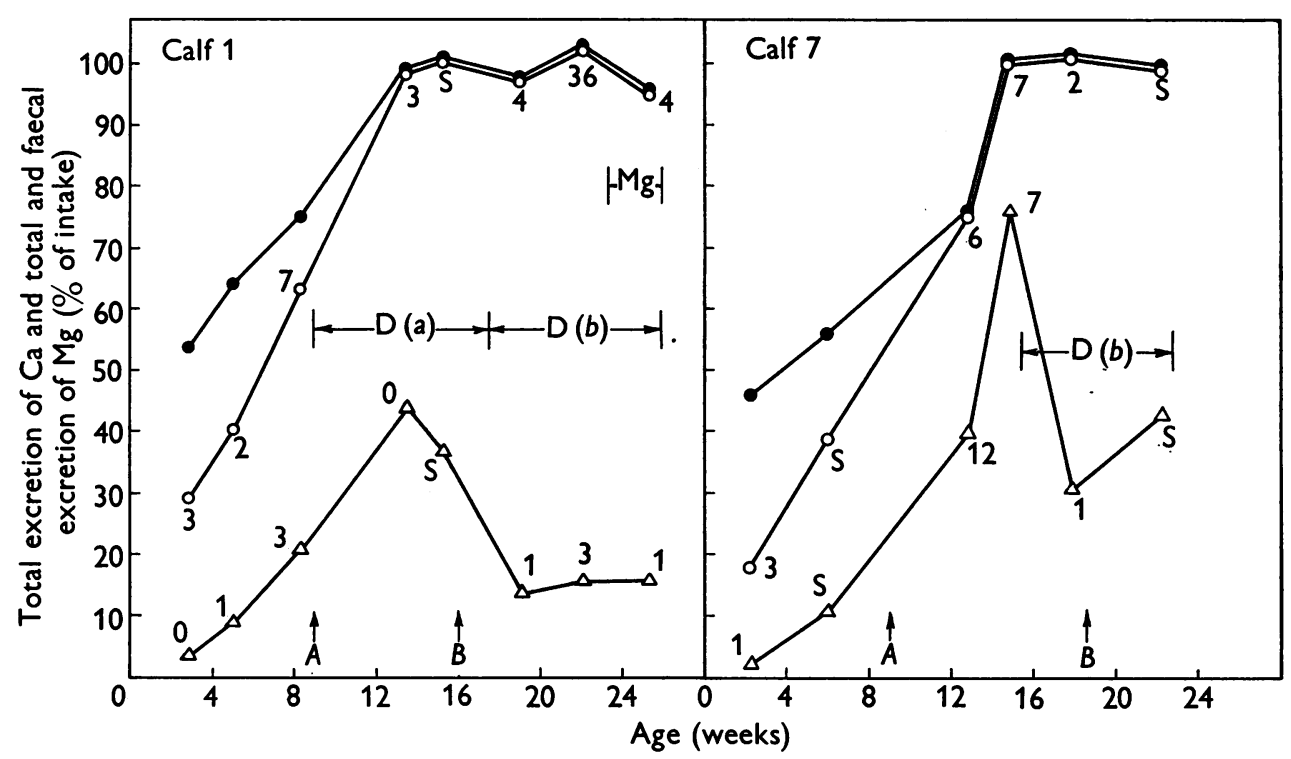

Fig. 3. Changes in total calcium excretion $(\triangle)$, total magnesium excretion $(O)$ and faecal magnesium excretion $(O)$ in calves 1 and 7. Excretion of calcium in the urine did not at any time exceed $1 \%$ of the intake. Each experimental point gives the mean result for a balance period. The recorded age was that corresponding to the middle of the period. When 8 days' balance experiments were carried out the first and last 4 days were evaluated separately. Figures shown beside the experimental points give the difference between the 8 days' means and the individual 4 days' means. This gives some indication of the reproducibility, although true differences between the two 4 days' periods must have occurred when the retention was changing rapidly. Big variations were almost always due to differences in the amounts of faeces voided; urine excretion of magnesium varied relatively little between adjacent 4 days' periods. Points corresponding to single 4 days' balance experiments are marked with an S. The young calves received 4.40 l. of milk/day. This was first increased to 6.15 l./day (point $A$ ) and then to $8 \cdot 80$ l./day (point $B$ ). Periods during which supplements were added to the diet are indicated $\left[D(a): 7000\right.$ i.u. of vitamin $D_{2} /$ day; $\mathrm{D}(\mathrm{b}): 70000 \mathrm{i} . \mathrm{u}$. of vitamin $\mathrm{D}_{2} / \mathrm{day} ; \mathrm{Mg}$ : magnesium (as the chloride) equivalent to $10 \mathrm{mg}$. $/ 100 \mathrm{ml}$. of diet]. The magnesium content of the unsupplemented milk is shown in Fig. 1. 
urine excretion of calcium greater than $1 \%$ of the intake. Since in addition appreciable hypercalcaemia was never observed, it seems unlikely that the calcium retentions at these levels of vitamin $D$ intake were abnormally high.

\section{Clinical signs}

Calves 85 and 7 both suffered a number of convulsions during the period in which their plasma calcium was reduced to about $50 \%$ of normal. The animals suddenly collapsed, frequently while they were being fed, and remained almost motionless with their necks and legs stiff for periods varying from a few minutes to about a half an hour. Although the plasma magnesium was below normal in both the calves at this time (about $1.4-1.5 \mathrm{mg} . / 100 \mathrm{ml}$.) such levels were never, at other times in our experiments in these or other calves, associated with convulsions. Since in addition the convulsions were unlike those previously reported for low-magnesium tetany (Blaxter, Rook \& MacDonald, 1954) and restoration of plasma calcium by the addition of vitamin $\mathrm{D}$ to the diet immediately stopped the convulsions, it appears that the effect was due to hypocalcaemia rather than to hypomagnesaemia. None of the other animals showing hypocalcaemia was observed to have convulsions but restoration of plasma calcium by the addition of vitamin $D$ to the diet was effected in all these calves before the plasma-calcium level dropped to $50 \%$ of normal. Apart from the low-calcium convulsions, none of the animals showed any obvious clinical signs until the plasma-magnesium level had dropped below about $1 \mathrm{mg}$. $/ 100 \mathrm{ml}$. They then usually showed some of the initial signs of hypomagnesaemia (Blaxter et al. 1954), becoming nervous and apprehensive with twitching ears and staring eyes. After they had been grossly hypomagnesaemic (plasma magnesium about $0.4-0.8 \mathrm{mg}$. $/ 100 \mathrm{ml}$.) for about a month, the calves were sometimes found to be staggering or unable to stand. No convulsions were seen but may have occurred when the calves were not under observation. Calves 3, 6 and 7 died during the night at 33,39 and 34 weeks of age respectively. Calves 1 and 4 were slaughtered when unable to stand at 29 and 46 weeks of age respectively. The other calves were slaughtered or transferred to other experiments without showing serious clinical signs of hypomagnesaemia.

\section{Growth}

If the weights of the calves that did not develop persistent digestive disturbances were plotted against the logarithms of their age, close agreement

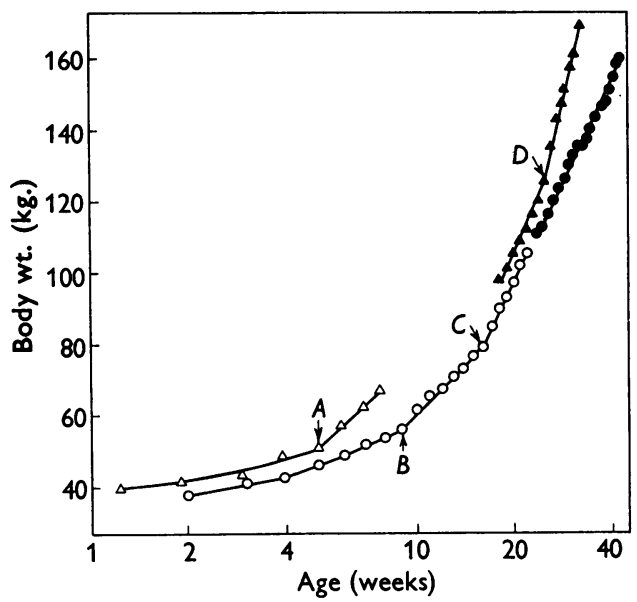

Fig. 4. Increase in weight expressed against a logarithmic age scale of $O$, calves, $1,3,4$ and 6 (mean values); $\Delta$, calves 85,86 and 87 (mean values); 0 , calf $4 ; \Delta$, calf 5 . Changes in the amount of milk fed (l./day) are indicated: $A, 4 \cdot 40$ to $6 \cdot 60 ; B, 4 \cdot 40$ to $6 \cdot 15 ; C, 6 \cdot 15$ to $8 \cdot 80 ; D, 8 \cdot 80$ to $13 \cdot 20$.

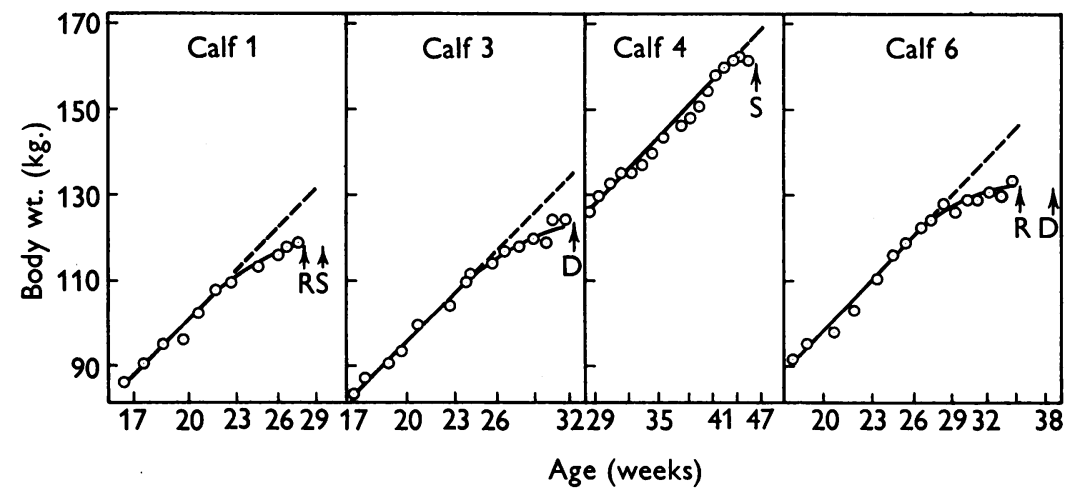

Fig. 5. Increase in weight expressed against a logarithmic age scale for periods during which the plasma magnesium of the calves fell below $0.8 \mathrm{mg}$./100 ml. Milk offered was $8.80 \mathrm{l}$./day in all cases. $\mathrm{R}$, Subsequently refused part of diet; $\mathrm{D}$, died; S, slaughtered when unable to stand. 
to a straight line was obtained for any one level of milk intake during most of the life of each calf after it was a few weeks old (Fig. 4). Within our limits the slope of the line increased with increasing milk intake. For each calf, the linear relationship continued from the period in which magnesium was being absorbed efficiently and the plasma-magnesium level was normal into the period in which magnesium absorption was poor and the plasmamagnesium level was falling. Furthermore, during most of the experiment, no appreciable growth differences were observed between similarly fed calves which developed hypomagnesaemia rapidly and slowly respectively. Thus although no comparison was made with milk-fed animals not developing hypomagnesaemia, it seems likely that magnesium deficiency did not inhibit the growth of the calves during the period that the linear relationship persisted. It was, however, observed that when gross hypomagnesaemia had developed (plasma magnesium about $0.4-0.8 \mathrm{mg} . / 100 \mathrm{ml}$.), and shortly before the appearance of serious clinical signs, the growth rate sometimes fell abnormally without any reduction in milk intake (Fig. 5).

\section{DISCUSSION}

Figures for the distribution of magnesium in the bodies of calves and adult bovines (Hogan \& Nierman, 1927) show that of the magnesium retained by a normal calf $60-80 \%$ is laid down in the bone. The data of these workers also show that about $99 \%$ of the retained calcium is laid down in bone. Our own results on calves a few weeks old (unpublished observation) and the results of Knoop, Krauss \& Hayden (1939) on non-hypomagnesaernic calves about 8 months old both show that the calcium : magnesium ratio in bone is about 45:1-55:1. Consequently it can be calculated that a growing calf with a normal calcium metabolism would need to retain calcium:magnesium in a ratio between about $46: 1$ and $32: 1$ in order just to maintain this ratio in the bone and to supply the magnesium needs of the soft tissue. Milk fed in the 1955-56 experiments contained calcium and magnesium in the ratio of about 10:1 and calves receiving this milk with adequate vitamin $D$, and growing at a normal rate, have been shown to retain about $80-95 \%$ of the dietary calcium. Thus it might be expected that a retention somewhere between about $20-30 \%$ of the intake would be sufficient just to satisfy the requirement of such calves for magnesium.

Our balance experiments indicate therefore that for young calves up to about 5 weeks of age a milk diet provided more than adequate magnesium. The magnesium retention was greater than the above theoretically deduced figure, and considerable amounts of magnesium were excreted in the urine.
During this period the plasma-magnesium levels were normal. The subsequent appearance of hypomagnesaemia in the calves as they got older was apparently due to the progressive decrease in their ability to utilize dietary magnesium until the retention fell below a critical value. Our balance measurements were too infrequent to give any definite indication of this critical retention, but for calves receiving milk with no supplementary magnesium the results were not inconsistent with the above theoretically derived figure of $20-30 \%$ of the intake. It appears therefore that the rate at which any particular milk-fed calf develops hypomagnesaemia is determined partially by the magnesium content of the diet but partially also by the rate at which the decrease in magnesium utilization occurs.

As a consequence of the decrease in magnesium utilization, the minimum dietary requirement of a milk-fed calf for magnesium will, in general, increase greatly with age, and it seems that the figures of 13.5 and $16-18 \mathrm{mg} . / 100 \mathrm{ml}$. of diet given by Blaxter et al. (1954) and Blaxter \& Rook (1954) respectively as a measure of this requirement cannot be generally applied. These figures were derived from observations of plasma levels and balance data at unspecified ages on young calves fed on synthetic milk up to about 13 weeks of age. They appear from our results to be roughly applicable to some calves in the region of 8-14 weeks of age, but to be usually too high for younger calves (which excreted much magnesium in the urine on diets containing about this level of magnesium) and usually too low for older calves (which developed hypomagnesaemia on diets containing these and higher levels of magnesium). Huffman et al. (1941) also observed hypomagnesaemia in calves receiving milk diets containing more magnesium than $13.5-18 \mathrm{mg}$./ $100 \mathrm{ml}$. and they estimated a minimum requirement of $30-40 \mathrm{mg} . / \mathrm{kg}$. body wt. (or about 30 $40 \mathrm{mg} . / 100 \mathrm{ml}$. of diet when a milk intake of about $10 \%$ body wt. is assumed) more or less permanently, to protect milk-fed calves from hypomagnesaemia. This dietary level was presumably sufficiently high to allow adequate magnesium retention even with poor magnesium utilization similar to that which we observed in our older calves. It should be pointed out that, although the calves which we used for balance experiments often showed no retention of magnesium, an appreciable negative balance was never observed. Some magnesium must have been absorbed therefore, even with zero retention, in order to account for endogenous faecal excretion. Support for a magnesium requirement in the region of $30-40 \mathrm{mg} . / 100 \mathrm{ml}$. of diet for older milk-fed calves is offered by our finding that an increase in the level of magnesium in the diet to about $34 \mathrm{mg} . / 100 \mathrm{ml}$. led to a marked recovery in the 
plasma-magnesium level of grossly hypomagnesaemic calves but an increase to about $22 \mathrm{mg}$./ $100 \mathrm{ml}$. did not.

The decrease in magnesium utilization as milkfed calves get older could be brought about by a decrease in absorption or an increase in endogenous faecal excretion or a combination of both. Only if the changes involved were physiological would our results support the contention of Blaxter (1956) that hypomagnesaemia under these conditions is due simply to a shortage of magnesium in the diet.

Thealternative, which on general groundsappears more likely, is that the changes were due, at least in part, to an abnormal condition arising from the particular properties of the milk diet. In view, however, of the lack of data on the endogenous faecal excretion of calves a few months old and on the ability of normally fed calves of this age to absorb magnesium, the question cannot at present be decided.

The hypocalcaemia which occurred in some of our calves in the absence of a dietary supplement of vitamin $D$ appeared to be due to the calves possessing a decreased ability to retain dietary calcium as they got older. Normal milk contains little vitamin D (0.3-1.7 i.u./100 g. in winter and 2.4-3.8 i.u./ $100 \mathrm{~g}$. in summer; Bicknell \& Prescott, 1953) and this disturbance in calcium metabolism might be considered to be due simply to vitamin $\mathrm{D}$ deficiency. However, two of our calves showed signs of faulty calcium metabolism with supplementary intakes of 7000 i.u./day, and Parr (1957) has reported hypocalcaemia in milk-fed calves a few weeks old (body wt. about 40-50 kg.) receiving a daily vitamin $D$ supplement of 430 i.u. It has been shown that on normal rations (grain and hay) alves do not develop rickets on daily vitamin $D$ intakes of about $4 \cdot 4-6 \cdot 6$ i.u. $/ \mathrm{kg}$. body wt. and that even with daily intakes as low as 2.6-3.3 i.u./kg. body wt. hypocalcaemia does not occur despite slight clinical symptoms of rickets (Bechdel, Hilston, Guerrant \& Dutcher, 1938; Thomas \& Moore, 1951). On similar rations calcium retention has been shown to be normal for calves receiving about 450 i.u. of vitamin D/day (Wallis, Palmer \& Gullickson, 1935). It is possible therefore that the primary cause of hypocalcaemia in milk-fed calves is something other than a dietary deficiency of vitamin $D$, but that exceptionally large amounts of vitamin $D$ can counteract whatever is responsible.

The apparent correlation which was observed, in the absence of supplementary vitamin $D$, between changes in plasma calcium and magnesium levels respectively and, in the cases examined, between changes in calcium and magnesium retention respectively suggests the possibility of a related cause for the calcium and magnesium upsets. The reason for this is unknown. It is of interest that
Allcroft (1947) has reported that of 406 cows developing hypomagnesaemia $\mathbf{7 5} \%$ also showed hypocalcaemia.

It has been shown both for calves (Blaxter et al. 1954 ; Parr, 1957 and our own unpublished observations) and for rats (Cunningham, 1936) that soft tissues, unlike bone, are not depleted of magnesium even under the most advanced conditions of magnesium deficiency. The fact that the growth of our animals did not appear to be affected during the initial onset of hypomagnesaemia suggests therefore that during this period the magnesium requirements of the new soft tissues were being fully supplied, presumably at the expense of the bone stores. It seems probable that the reduced rate of growth observed in our grossly hypomagnesaemic calves corresponded to a time when their available magnesium stores were almost exhausted, a suggestion which is supported by the fact that this frequently formed a prelude to the appearance of serious clinical signs and death. Tufts \& Greenberg (1938) found that inhibition of growth in rats on a magnesium-deficient diet did not occur until after clinical signs of magnesium deficiency had appeared.

\section{SUMMARY}

1. Calves were fed on diets consisting basically of whole milk for up to 46 weeks. At ages less than 5 weeks they were shown to retain $39-54 \%$ and to excrete in the urine 13-34\% of their dietary mag. nesium.

2. The hypomagnesaemia, which sooner or later appeared as the calves got older, was shown to be associated with a progressive decrease in their ability to utilize dietary magnesium. This decrease continued until little or no magnesium was retained or excreted in the urine.

3. Hypocalcaemia, which also occurred in some of the calves when inadequate vitamin $D$ was present in the diet, appeared to be associated with a decrease in their ability to utilize dietary calcium. This decrease may have been related to the decrease in their ability to utilize magnesium, but the addition of a high level of vitamin $\mathrm{D}$ to the diet led to a marked improvement in calcium utilization only. The amount of vitamin $D$ required to restore and maintain normal calcium retention appeared, in some cases, to be exceptionally high.

4. The changes in the plasma-magnesium and -calcium levels did not appear to be associated with any changes in the plasma inorganic-phosphorus level or in the proportions of plasma magnesium and calcium which were ultrafilterable.

5. Growth of the calves appeared to be unaffected during the early stages of magnesium deficiency. It was, however, sometimes inhibited after a long period of gross hypomagnesaemia. 
The author would like to thank Professor H. D. Kay, C.B.E., F.R.S., for his interest and advice. He would also like to thank Mr H. S. Hallett, B.E.M., for assistance with the analytical work and Mr P. A. Hursey and Miss P. Lewis for general technical assistance.

\section{REFERENCES}

Allcroft, W. M. (1947). Vet. J. 103, 2.

Bechdel, S. I., Hilston, N. W., Guerrant, N. B. \& Dutcher, R. A. (1938). Bull. Pa agric. Exp. Sta. no. 364.

Bicknell, F. \& Prescott, F. (1953). The Vitamins in Medicine, 3rd ed., p. 542. London: Heinemann.

Blaxter, K. L. (1956). Ciba Foundation Symposium on Bone Structure and Metabolism, p. 117. London: Churchill.

Blaxter, K. L. \& McGill, R. F. (1956). Vet. Rev. Annot. 2, 35.

Blaxter, K. L. \& Rook, J. A. F. (1954). J. comp. Path. 64, 176.

Blaxter, K. L., Rook, J. A. F. \& MacDonald, A. M. (1954). J. comp. Path. 64, 157.

Blaxter, K. L. \& Sharman, G. A. M. (1955). Vet. Rec. 67, 108. Cunningham, I. J. (1936). N.Z. J. Sci. Tech. 18, 419.

Duncan, C. W., Huffman, C. F. \& Robinson, C. S. (1935). J. biol. Chem. 108, 35.

Duncan, C. W., Lightfoot, C. C. \& Huffman, C. F. (1938). J. Dairy Sci. 21, 689.
Fiske, C. H. \& Subbarow, Y. (1925). J. biol. Chem. 66, 375. Godden, W. (1937). Tech. Commun. Bur. Anim. Nutr., Aberd., no. 9, p. 39.

Gregory, M. E. (1954). Brit. J. Nutr. 8, 342.

Hogan, A. G. \& Nierman, J. L. (1927). Res. Bull. Mo. agric. Exp. Sta. no. 107.

Huffman, C. F., Conley, C. L., Lightfoot, C. C. \& Duncan, C. W. (1941). J. Nutr. $22,609$.

Huffman, C. F. \& Duncan, C. W. (1936). J. Dairy Sci. 19, 440.

Huffman, C. F. \& Robinson, C. S. (1926). J. biol. Chem. 69, 101.

Knoop, C. E., Krauss, W. E. \& Hayden, C. C. (1939). J. Dairy Sci. 22, 283.

McSherry, J. \& Grinyer, I. (1954). Amer. J. vet. Res. 15, 509.

Parr, W. H. (1957). Vet. Rec. 69, 71.

Russell, F. C. (1944). Tech. Commun. Bur. Anim. Nutr., Aberd., no. 15, p. 69.

Thomas, J. W. \& Moore, L. A. (1951). J. Dairy Sci. 34, 916.

Tufts, E. V. \& Greenberg, D. M. (1938). J. biol. Chem. 122 , 693.

Wallis, G. Carrol, Palmer, L. S. \& Gullickson, T. W. (1935). J. Dairy Sci. 18, 213.

Wise, G. H., Petersen, W. E. \& Gullickson, T. W. (1939). J. Dairy Sci. 22, 559.

\title{
A New Type of Esterase in Hog-Kidney Extract
}

\author{
BY F. BERGMANN, RUTH SEGAL AND SARA RIMON* \\ Department of Pharmacology, The Hebrew University-Hadassah Medical School, Jerusalem, Israel
}

(Received 24 January 1957)

Among mammalian esterases, two different types have been distinguished in recent years: (1) esterases which are inhibited by certain organophosphorus compounds [the B-esterases of Aldridge (1953a)]; (2) hydrolytic enzymes which use the above inhibitors as substrates (the so-called Aesterases; Aldridge, 1953a). Activity of the first group of enzymes is based on the presence in the active centre of an imidazole group (Wilson \& Bergmann, 1950; Bergmann, Segal, Shimoni \& Wurzel, 1956) and probably serine (Schaffer, May \& Summerson, 1953, 1954; Oosterbaan, Kunst \& Cohen, 1955). The A-esterases, on the other hand, are believed to contain a sulphydryl group since they are sensitive to heavy metals, notably mercuric derivatives, to nickel and copper salts and are also inhibited to a certain degree by iodoacetate (Aldridge, 1953b). However, the pH-activity curves for the hydrolysis of diethyl $p$-nitrophenyl phosphate by A-esterase from rabbit's serum (Aldridge, 1953b) and of diisopropyl phosphoro-

* Part of a Ph.D. thesis submitted to the Faculty of Science, The Hebrew University, Jerusalem, Israel. fluoridate (DFP) by the enzyme (DFPase) of hog kidney (Mounter, 1956) that hydrolyses DFP and other dialkyl phosphorofluoridates show a maximum at $\mathrm{pH} 7 \cdot 6$, similar to cholinesterases and aliesterases (Bergmann et al. 1956). These facts suggest that the active centres of A-esterases contain an imidazole ring as well as a sulphydryl group. The activity of both groups of esterases is thus based on the same fundamental principle, namely the presence of an imidazole ring, but is modified by the inclusion of either an alcoholic hydroxyl or a sulphydryl group.

It appeared of interest to test the A-esterases against carboxylic esters. Aldridge $(1953 b)$ has already reported that the enzyme from rabbit's serum acts on a special group, namely $p$-nitrophenyl esters. We have investigated systematically kidney DFPase against carboxylic esters as substrates, and observed that a new type of esterase is present in addition to the A-esterase. Since, according to Aldridge's nomenclature, A-esterases are not inhibited by organophosphorus compounds and do in fact hydrolyse them, and B-esterases are inhibited

Bioch. 1957, 67 